and with a wealth of reference to interesting observations and discoveries that the author has made. For those who demand something more for the examination table, there is a short appendix of the forms of life arranged systematically. There are also a list of books suggested for further reading and a good index. Indeed, the only thing one can complain about are the illustrations, which are unnecessarily sketchy and crude for a book that is otherwise produced on a standard commensurate with its price.

$$
\text { W. E. SwInton }
$$

\section{OBITUARIES OF THE PILTDOWN REMAINS}

Further Contributions to the Solution of the Piltdown Problem

Bulletin of the British Museum (Natural History) : Geology, Vol. 2, No. 6 (1955).

The Piltdown Forgery

By Dr. J. S. Weiner. Pp. xii $+214+8$ plates. (London: Oxford University Press, 1955.) 12s.6d.net.

T HE Piltdown saga has now been concluded. The British Museum (Natural History) has brought together under the title "Further Contributions to the Solution of the Piltdown Problem" in its Bulletin (Vol. 2, No. 6) the views of a large number of specialists who have described their work on the specimens-work which has resulted in demonstrating without any doubt that the whole thing was a hoax. This is an important publication, as we have here, clearly set out, the methods now at our disposal to check discoveries, and are shown how they demonstrate that the Piltdown finds were not genuine. These methods have to some extent been perfected as a result of the Piltdown re-investigation, and to that extent the 'hoax' has been useful. The late Sir Arthur Smith Woodward had not these methods of study at his disposal and therefore cannot be blamed for having failed to spot the imposition. Unfortunately, he had casts made almost at once, which were mainly used by savants when studying the specimens. No cast, however well made, can give the minute scratches such as those which in the case of the teeth were of great significance. I was a youngster at the time and never a 'bone' man; but I was one of a not too numerous band who was allowed to handle the originals in Smith Woodward's room at the Museum soon after they had been presented at a meeting of the Geological Society. But even if I had had the knowledge to judge the matter, it would not have occurred to me to question their authenticity.

Dr. J. S. Weiner's book, "The Piltdown Forgery", deals rather with the many personalities in the case. For this reason it will have a very popular appeal. It is exceedingly well written and gives one a vivid picture of the group of keen amateurs, most of them friends of old Ben Harrison, of Eolithic fame, who were concerned at the time with Sussex geology and archæology. We are lod relentlessly to one conclusion, whish, though it can never be absolutely proved, is the only one which fits the facts. Th" story unfolds with the discovery of Piltdown I, ard we find not a few of the local amateurs a litcle suspicious that all is not as presented. We now have evidence for staining of specimens; we have the 'happy' find of Piltdown II which was to clinch the matter. There was even more in the background which never appeared until much later.

It all reads like a novel, and I have no intention of spoiling it for others by saying more. It is a book to be read with interest and profit. Such a hoax nowadays is impossible; but it was one actually perpetrated and it was a great success.

Miles C. BurktmT

\section{TREATISE ON VITAMINS}

The Vitamins

Chemistry, Physiology, Pathology. Edited by W. H. Sebrell, Jr., and Professor Robert S. Harris. Vol. 1. Pp. xiii +676. Vol. 2. Pp. xiii +766. Vol. 3. Pp. xiii +665. (New York: Academic Press, Inc.; London: Academic Books, Ltd., 1954.) Vols. 1 and 2, 16.50 dollars each. Vol. 3, 15 dollars.

DRING the second half of 1954 these three volumes have appeared in quick succession, and the series is now complete. It is a monumental undertaking, and will immediately take its place as a standard reference work, and source book, for everyone doing research on the biochemistry of vitamins. The scope of the enterprise is apparent from the fact that Vol. 1, running to 676 pages, has four chapters dealing with vitamin $A$, vitamin $C$, vitamin $B_{12}$, and biotin; Vol. 2, in 766 pages, covers six furthor vitamins (choline, D, "F", inositol, $K$, nicotinamide and pantothenic acid), while Vol. 3 in 665 pages takes up the topics of PABA, folic acid, $B_{6}$, riboflavin, $B_{1}$, $\mathrm{E}$ and other factors.

Each chapter in turn contains a dozen or so sections, by separate authors, dealing successively and systematically with such matters as nomenclature, chemistry, industrial preparation, biochemical systems, specificity of action, biogenesis, assay, standardization, distribution in foodstuffs, effects of deficiency in animals, deficiency in human beings, pharmacology, pathology, requirements of animals, and human beings, and even "futuro problems". The individual sections are further split up into sub-sections, and these into sub-sub-sections. There is no doubt that this is far and away the most comprehensive treatment of the subject that has so far appeared in a single treatise. Nevertheless, it is not exhaustive. The clinical manifestations of vitamin deficiency and their treatment are not described in any detail, nor are the methods of vitamin assay, the reason given being that these matters are already fully dealt with elsewhere.

The undertaking is essentially American. (In Vol. 1, seven of the eleven authors are from the United States, two from Germany, and two from Britain. In Vol. 2, of the nineteen authors, seventeen are American, and the remaining two Canadian. In Vol. 3, twenty-two authors are American, and one is Dutch.) It is in consequence of this fact, perhaps, that in several of the sections the bibliography does not quite fairly cover the whole of the international scene, but deals too exclusively with the American literature, which is presumably more accessible but, chronologically speaking, not always the 'first in the field'. All the same, any serious investigator desiring to make contact with the existing scientific literature could not do better than start the search with "Sebrell and Harris". We owe a debt of gratitude to the editors and to the authors for their most successful endeavour.

LESLIE J. HARRIS 